\title{
Penerapan Model Discovery Learning dengan Media Konkret untuk Meningkatkan Pembelajaran Matematika tentang Bangun Datar pada Siswa Kelas IV SD Negeri 2 Tamanwinangun Tahun Ajaran 2019/2020
}

\author{
Rezkia Widya Safitri ${ }^{1}$, Wahyudi $^{2}$, Ngatman $^{3}$ \\ 1,2,3 Universitas Sebelas Maret \\ safitri12@gmail.com
}

\section{Article History}

accepted 01/02/2020

\begin{abstract}
This study aimed to describe the steps to the application of Mathematics learning model about plane figures to fourth grade students. It was a Collaborative Classroom Action Research (CAR) conducted in three cycles. Each of them consisted of two meetings. The data were quantitative data and qualitative data. Data collection techniques included tests, observations, interviews, and documentation. Data validity used triangulation of techniques, triangulation of sources, and content validity. Data validity included data reduction, data presentation, and drawing conclusions. The study indicates that application of Discovery Learning model with concrete materials improves mathematics learning about plane figures. It was proven by the increase of students' learning mastery: $88 \%$ in first cycle, $92 \%$ in second cycle, and $94 \%$ in third cycle.
\end{abstract}

Keywords: Discovery Learning, Concrete Materials, Mathematics

\begin{abstract}
Abstrak
Penelitian ini bertujuan untuk mendeskripsikan langkah-langkah penerapan model pembelajaran Matematika tentang Bangun Datar pada siswa kelas IV. Penelitian ini merupakan Penelitian Tindakan Kelas (PTK) kolaboratif dilaksanakan dam tiga siklus yang setiap siklusnya terdiri dari dua pertemuan. Data yang digunakan adalah data kuantitaif dan data kualitatif. Teknik pengumpulan data menggunakan tes, observasi, wawancara, dan dokumentasi. Validitas data menggunakan triangulasi teknik, triangulasi sumber dan validitas isi. Validitas data meliputi reduksi data, penyajian data, dan penarikan kesimpulan. Hasil penelitian menunjukkan bahwa penerapan model Discovery Learning dengan media konkret dapat meningkatkan pembelajaran Matematika tentang Bangun Datar yang diketahui melalui kenaikan rata-rata persentase ketuntasan siswa sebesar $88 \%$ pada siklus I, $92 \%$ pada siklus II, 94\% pada siklus III.
\end{abstract}

Kata Kunci: Discovery Learning, Media Konkret, Matematika. 


\section{PENDAHULUAN}

Menurut Nurasiah (2015: 241) dan Wahyudi (2015: 68) matematika adalah suatu bahan kajian yang objeknya abstrak yang berbentuk bahasa simbol dan dibangun melalui penalaran deduktif yaitu kebenaran sebelumnya yang sudah diterima, keterkaitan antar konsep bersifat kuat dan jelas.

Menurut Wahyudi (2015: 68) tujuan matematika diajarkan kepada siswa untuk melatih cara berfikir secara sistematis, konsisten, logis, kritis, dan kreatif.

Berdasarkan observasi dan wawancara yang dilakukan pada 7 Oktober 2019 dengan wali kelas III, didapatkan data bahwa kondisi pembelajaran Matematika di SD Negeri 2 Tamanwinangun ditinjau dari tujuan Matematika siswa belum memiliki sikap berifikir yang logis, kritis, dan kreatif. Terbukti ketika proses pembelajaran berlangsung siswa masih terlihat kurang antusias dalam pembelajaran, pada saat diskusi kelompok juga siswa kurang aktif dan mengeksplor materi pembelajaran. Siswa merasa pembelajaran Matematika tidak menarik dan susah karena banyak menhitung dan menghafal rumus apalagi tidak adanya media yang mengkonkretkan materi tersebut menggunakan benda nyata.

Dilihat dari proses pembelajaran Matematika yang belum menggunakan model pembelajaran inovatif dan dapat mengaktifkan siswa, ketika guru menjelaskan materi pembelajaran guru hanya menggunakan metode ceramah dan latihan soal, guru juga belum menggunakan media konkret yang dapat menggambarkan tentang materi pada hari itu. Supaya pembelajaran Matematika mengasikakan, sebaiknya guru menggunakan model pembelajaran yang inovatif.

Inovasi dalam pembelajaran tersebut bertujuan untuk meningkatkan kualitas dan keaktifan siswa dalam pembelajaran. Salah satu model yang dapat diterapkan ialah model pembelajaran Discovery Learning.

Hosnan (2014: 282) Discovery Learning adalah suatu model pembelajaran siswa aktif dengan menemukan dan menyelidiki secara mandiri, sehingga hasil belajar yang diperoleh tahan lama dalam ingatan siswa. Discovery Learning dikembangkan oleh Bruner. Tipe ini mengkombinasikan keunggulan pembelajaran kooperatif dan pembelajaran individual.

Berdasarkan uraian di atas, peneliti tertarik untuk melaksanakan penelitian tindakan kelas yang berjudul "Penerapan model Discovery Learning dengan Media Konkret untuk Meningkatkan Pembelajaran Matematika tentang Bangun Datar pada Siswa Kelas IV SD Negeri 2 Tamanwinangun Tahun Ajaran 2019/2020".

Diharapkan dengan penelitian ini dapat meningkatkan keaktifan siswa serta dapat memberikan pengalaman nyata, sehinga mengubah konsep yang abstrak menjadi lebih konkret.

Berdasarkan uraian di atas, maka dapat dirumuskan masalah yang muncul yaitu: (1) bagaimanakah langkah-langkah penerapan model Discovery Learning dengan media konkret dalam peningkatan pembelajaran Matematika tentang Bangun Datar di kelas IV SD Negeri 2 Tamanwinangun, (2) apakah penerapan Discovery Learning dengan media konkret dapat meningkatkan pembelajaran Matematika di kelas IV SD Negeri 2 Tamanwinangun, dan (3) Kendala dan solusi apa saja yang ditemukan pada penerapan model Discovery Learning dengan media konkret dalam peningkatan pembelajaran Matematika tentang Bangun Datar di kelas IV SD Negeri 2 Tamanwinangun.

\section{METODE}

Metode penelitian yang digunakan dalam penelitian ini berupa penelitian tindakan kelas kolaboratif. Peneliti berkolaborasi dengan guru kelas IV SDN 2 Tamanwinangun tahun ajaran 2019/2020. Pada penelitian ini, peneliti hanya melibatkan guru sebagai tim pokok untuk melaksanakan tindakan. Peneliti hanya bertindak sebagai perencana dan observer. Penelitian tindakan kelas ini menggunakan model penelitian yang 
dikembangkan Arikunto, Suhardjono \& Supardi (2014: 16) yang setiap siklusnya terdiri dari tahap perencanaan, pelaksanaan, pengamatan, dan refleksi.

Subjek dalam penelitian ini adalah siswa kelas IV SD N 2 Tamanwinangun yang berjumlah 25 siswa. Jenis data penelitian ini adalah data kualitatif berupa hasil observasi dan wawancara penerapan model pembelajaran Discovery Learning dengan media konkret dan data kuantitatif berupa hasil tes siswa dalam mata pelajaran Matematika.

Teknik pengumpulan data menggunakan tes, obsservasi, wawancara dan dokumentasi. Validitas data menggunakan triangulasi teknik, triangulasi sumber dan validitas isi. Analisis data meliputi reduksi data, penyajian data, dan penarikan kesimpulan. Indikator kinerja penelitian ini adalah peningkatan pembelajaran Matematika dengan target yang ditetapkan $85 \%$ dan ketuntasan minimal siswa dengan target $85 \%$.

\section{HASIL DAN PEMBAHASAN}

Penelitian ini dilaksanakan selama tiga siklus dengan menerapkan enam langkah model Discovery Learning dengan media konkret. Menurut Wahjudi, E. (2015:2-3) dalam mengaplikasikan Discovery Learning ada beberapa prosedur yang harus dilaksanakan, antara lain: (1) Stimulation, (2) problem statement, (3) Data collection, (4) Data Processing, (5) Verification, (6) Generalization. Hasil observasi terhadap pelaksanaan pembelajaran Matematika dengan menerapkan model Discovery Learning dengan media konkret mengalami peningkatan pada setiap siklusnya yaitu:

Tabel 1. Persentase Hasil Observasi Penerapan model pembelajaran Discovery Learning dengan konkret

\begin{tabular}{lccc}
\hline Sumber & \multicolumn{3}{c}{ Siklus } \\
\cline { 2 - 4 } \multicolumn{1}{c}{ data } & $\mathrm{I}(\%)$ & $\mathrm{II}(\%)$ & $\mathrm{III}(\%)$ \\
\hline Guru & 85,71 & 87,38 & 90,17 \\
Siswa & 85,57 & 87,50 & 90,00 \\
\hline
\end{tabular}

Hasil pengamatan terhadap guru pada siklus I ke siklus II meningkat sebesar $1,67 \%$ dari $85,71 \%$, menjadi $87,38 \%$, dan pada siklus II ke siklus III meningkat sebesar $2,79 \%$ dari $87,38 \%$ menjadi $90,00 \%$. Persentase hasil pengamatan pada siswa juga mengalami peningkatan pada siklus I ke siklus II sebesar 1,93\% yaitu dari $85,57 \%$ menjadi $87,50 \%$ dan pada siklus II ke siklus III meningkat sebesar $2,5 \%$ dari $87,50 \%$ menjadi $90,00 \%$.

Tabel 2. Analisis Hasil Belajar Siswa Siklus I, II, dan III

\begin{tabular}{lccc}
\hline & \multicolumn{3}{c}{ Siklus } \\
\cline { 2 - 4 } & $\mathrm{I}(\%)$ & $\mathrm{II}(\%)$ & $\mathrm{III}(\%)$ \\
\hline Tuntas & 88 & 92 & 94 \\
Belum & 12 & 8 & 6 \\
Tuntas & & & \\
\hline
\end{tabular}

Berdasarkan data di atas, dapat diketahui bahwa rata-rata persentase ketuntasan hasil belajar siswa pada siklus I ke siklus II meningkat sebesar $4 \%$ dari $88 \%$ menjadi $92 \%$ dan dari siklus II ke siklus III meningkat sebesar $2 \%$ dari $92 \%$ menjadi $94 \%$.

Berdasarkan tabel 1 tersebut dapat disimpulkan bahwa penerapan model pembelajaran Discovery Learning dengan media konkret sudah dilaksanakan dengan baik dan sudah melampaui target indikator kinerja penelitian yang ditetapkan yaitu sebesar $85 \%$. Berdasarkan tabel 2 dapat disimpulkan bahwa ketuntasan minimal siswa 
sudah meampaui target indikator kinerja penelitian yang ditetapkan sebesar $85 \%$ dan terdapat kenaikan hasil belajar siswa di setiap siklusnya.

\section{SIMPULAN}

Berdasarkan hasil penelitian dan pembahasan yang telah diuraikan, maka dapat disimpulkan bahwa: (1) penerapan model Discoveri Learning dengan media konkret dilakukan dengan enam langkah yaitu: (a) stimulation dengan media konkret, (b) problem statement dengan media konkret, (c) data collection dengan media konkret, (d) data processing dengan media konkret, (e) verification dengan media konkret, ( $f$ ) generalization dengan media konkret. ; (2) Penerapan model Discovery Learning dengan media konkret dapat meningkatkan pembelajaran Matematika tentang Bangun Datar pada siswa kelas IV SD N 2 Tamanwinangun yang dilihat dari kenaikan persentase ketuntasan siswa yaitu pada siklus I sebesar $88 \%$, pada siklus II meningkat menjadi 92\%, dan pada siklus III meningkat menjadi 94\%; (3) Kendala yang dihadapi pada saat melaksanakan model Discovery Learning dengan media konkret adalah (a) siswa belum berani untuk bertanya hal-hal yang belum dipahami, (b) pembelajaran masih didominasi guru, (c) kondisi kelas gaduh ketika berdiskusi, (d) beberapa langkah terlewat, (e) siswa kurang aktif dalam memebri tanggapan hasil diskusi, (f) masih sedikit siswa yang bertanya, (g) tidak semua siswa ikut berkerja saat berdiskusi dan menyita banyak waktu. Illahi (2012: 70-73) yang menyatakan bahwa kekurangan model discovery learning salah satunya banyak menyita waktu. Solusi yang yang dapat digunakan adalah (a) guru memberikan motivasi kepada siswa untuk menanyakan hal yang belum dipahami, (b) guru memberikan kesempatan siswa untuk mencari informasi secara berkelompok, (c) guru melakukan pengkondisian kelas, (d) mengarahkan guru untuk memperlajari kembali langkah-langkah yang telah direncanakan, (e) mengarahkan guru untuk mengondisikan siswa saatpersentasi untuk saling mennaggapi dan tanya jawab, (f) guru merangasang siswa untuk bertanya dengan cara memberikan pertanyaan kepada siswa, (g) guru mengarahkan siswa agar membagi tugas dalam kelompok sehingga pekerjaan kelompok yang dikerjakan cepat selesai.

Peneliti memberikan beberapa saran supaya kualitas pembelajaran semakin meningkat. Saran bagi siswa yaitu: mengikuti pembelajaran dengan semangat; bersungguh-sungguh; aktif bertanya serta berpendapat dengan percaya diri. Saran bagi guru yaitu: lebih memperhatikan waktu saat pembelajaran berlangsung; dalam kegiatan diskusi serta melakukan pengondisian kelas secara menyeluruh saat penggunaan media konkret. Saran bagi sekolah yaitu: pihak sekolah sebaiknya selalu melengkapi fasilitas pendukung pembelajaran seperti media pembelajaran, sehingga hasil pembelajaran lebih optimal dan pembelajaran lebih menyenangkan. Saran bagi peneliti lain adalah: peneliti lain sebaiknya membuat kegiatan pembelajaran yang lebih mengaktifkan siswa, inovatif dan kreatif, sehingga dapat meningkatkan kualitas pembelajaran yang sesuai.

\section{DAFTAR PUSTAKA}

Arikunto, S., Suhardjono, \& Supardi. (2014). Penelitian Tindakan Kelas. Jakarta: Bumi Aksara.

Hosnan. (2014). Pendekatan Saintifik dan Kontekstual dalam pembelajaran Abad 21. Bogor: Ghalia Indonesia.

Illahi, M. (2012). Pembeajaran Discovery Strategy \& Mental Vocational Skill. Yogyakarta: DIVA Press. 
Nurasiah, I. (2015). Model Pembelajaran Kooperatif dalam Mata Pelajaran Matematika Kelas V Sekolah Dasar. Membangun Imajinasi dan Kreativitas Anak melalui Literasi. 2(27) 239-247.

Wahjudi, E. (2015). Penerapan Discovery Learning Dalam Pembelajaran IPA Sebagai Upaya untuk Meningkatkan Hasil Belajar Siswa Kelas IX-I di SMP Negeri 1 Kalianget. Jurnal Lensa, 5 (1), 1-15. Diperoleh pada 19 November 2019, dari artikel.dikti.go.id/pelatihan/index.php/pojs04/article/download/571/249.

Wahyudi. (2015). Panduan Pembelajaran Matematika di Sekolag Dasar (Untuk Guru dan Calon Guru). Surakarta: UNS Press. 